\title{
The experience of development of spatial database in oil\&gas geology
}

Lobasov O. P., *Mironenko V. I., Galyuk S. M. (SE "Naukanaftogaz")

\section{SUMMARY}

The five year experience of development of spatial database in oil\&gas geology is given. This experience cause to review some initial principles of database elaboration and formation for such elements as data structure, interface functionality and formation strategy. The resent state of database development are shown.

Досвід розробки картографічної бази даних нафтогазової геології

Лобасов О. П., *Мироненко В. І., Галюк С. М. (ДП “Науканафтогаз”)

Опыт разработки картографической базы данных нефтегазовой геологии

Лобасов А. П., *Мироненко В. И., Галюк С. М. (ДП “Науканафтогаз”) 